\title{
Implementation Efforts of the Nationally Determined Contributions Under the Paris Agreement
}

\author{
Ratna Dhian Noventy*, Martani Huseini \\ Administrative Science Faculty \\ University of Indonesia \\ Jakarta, Indonesia \\ *ratnadhiannoventy@ymail.com, martani@huseini.com
}

\begin{abstract}
Under the Paris Agreement, countries around the world commit to achieving greenhouse gas emissions reduction targets as outlined in the Nationally Determined Contributions (NDCs). While existing NDCs are on track to realize its target, this article focuses on analysis of implementation efforts in various countries that have ratified the Paris Agreement. The methodology enhances literature study on journals, books, and news by complementing it with details representation of implementation challenges and policy recommendations captured by the Parties. The results indicate that the major barriers for NDCs implementation in some countries are caused by the current policies that are very strong in mandates but it is weak in inducements. It can be seen from the absence of regulatory framework and policy coordination from sectoral to sub-sectoral level in its region. It is also prompted by the gaps that are identified in knowledge and capacity. Lack of awareness and substantial understanding across various stakeholders are the problem in the field. Emerging that the current implementation efforts are not enough to realize greenhouse gas emissions reduction targets, a set of policy recommendations based on robust analysis and data are proposed to address the challenges and to achieve expected emissions under NDCs goal by 2030 .
\end{abstract}

Keywords-implementation, nationally

determined contributions, Paris agreement

\section{INTRODUCTION}

It is known that the negative impacts of climate change are felt by various communities [1]. Climate change can affect human health, including factors of infectious diseases, malaria, and mental health diseases [2-5]. Besides, Allen [2], mention that it will result in asthma and respiratory disease. Climate change in the perspective of economists produces exogenous shocks [6]. The results of research by Caruso et al. [6] mention that there is a positive analysis of the relationship between climate and conflicts that occurred in Indonesia during the 1993-2003 period. There are various people with an interest in the climate claiming that a very large climate impact can negate hopes of improving the welfare of society in the future [7]. Climate change also can reduce biodiversity [8]. A study conducted by Nunez et al. [9] predicted that it will decrease the number of mammals. Loss of biodiversity will prevent ecosystem imbalance or even damage existing ecosystems.

The current world climate change conditions are getting worse. Based on reports from the United Nations (UN), it is revealed that 2019 is the hottest year in the last five years. Earth's temperature in this period is estimated to have risen $1.1^{\circ} \mathrm{C}$ above the pre-industrial era $(1850-1900)$ and $0.2^{\circ} \mathrm{C}$ warmer from 2011-2015. Meanwhile, the World Meteorological Organization (WMO) in its report also stated that the concentration of carbon dioxide $\left(\mathrm{CO}_{2}\right)$ in the atmosphere broke a new record. Greenhouse gas (GHG) emissions in the atmosphere broke new records in 2018, exceeding the annual average increase in the previous decade and increasing the damage to weather patterns [10].

Preventing the worsening impact of climate change in the future, the United Nations (UN) General Assembly has made efforts to respond to this matter since 1990 through the establishment of the Intergovernmental Negotiating Committee (INC). Subsequently, in May 1992, INC adopted a legal framework namely the United Nations Framework Convention on Climate Change (UNFCCC) [11]. The UNFCCC aims to stabilize the concentration of GHG in the atmosphere at a level that does not endanger the Earth's climate. The stabilization of this GHG concentration is targeted to be achieved at a certain time period so that the earth's ecosystem has enough time to adapt to the changes that will occur. This GHG stabilization also aims to guarantee productivity in terms of food and develop countries' economies so that it can take place by promoting sustainable principles [12].

To achieve the goals mentioned above, UNFCCC formed a body in charge of taking decisions of the parties called the Conference of the Parties (COP). COP has a role to oversee the implementation of the convention, supervise the parties (states) in carrying out their obligations under the convention, provide facilities for exchanging information between countries, provide recommendations to the parties, and form supporting institutions if necessary.

At the $21^{\text {st }}$ COP 2015 in France on 30 November - 11 December 2015, the UNFCCC participants succeeded in 
agreeing on the adoption of the Paris Agreement. In general, the outcome of the Paris Agreement is that the agreement is binding, fair, balanced and applies to all parties. The agreement aims to decrease worldwide temperature grow to beneath $2^{\circ} \mathrm{C}$ from pre-industrial levels and to make efforts to restrict this to under $1.5^{\circ} \mathrm{C}$ [13]. A total of 197 countries have signed the Paris Agreement which presents an agenda and discusses the main issues for implementing efforts to tackle climate change by involving various local, regional, national and international stakeholders [14]. The climate change has made various countries in the world have a commitment to limit the rise in global temperatures because of the real impact of climate change which causes various disasters and can even lead to the extinction of humans [1].

Although this goal is formulated at the global level, the success rate of the Paris Agreement is determined by the implementation of climate policies by each country [15]. The Paris Agreement is a new stage in climate politics at the international level which is carried out domestically [16]. The Paris Agreement is not an end in the struggle for a climate change solution. This is because there is something more crucial, namely global commitment to the implementation that will be carried out. Achieving the goals of the Paris Agreement, national contributions to global efforts are set out in Nationally Determined Contributions (NDCs). In the document, various countries describe the transition to a lowemission and climate-resilient future based on reference targets that can be achieved by 2030 .

There are various countries that have a lack of experience in setting mitigation targets and developing climate policies in the face of the process for preparing NDCs, for example related to the limited available data and insufficient time [17] Moreover, the success of the Paris Agreement is determined by all parties' implementation of NDCs [18]. The implementation of the NDCs stage is a momentum for countries to further improve people's welfare through more intensive efforts, for example in protecting forests, protecting the environment, developing the application of new and renewable energy, increasing sustainable transportation, low-emission agriculture and increasing food security, environmentally-friendly industries, environmentally friendly buildings and integrated waste management [19].

However, in its implementation, there are often various challenges that can affect the success rate of NDCs implementation. Hence, it is important to conduct an assessment of the efforts to implement the NDCs policy in the Paris Agreement because the implementation of the NDCs will determine the fulfillment of targets in the form of emission reduction in 2030. The Paris Agreement will not be reached without a reduction in GHG emissions [14]. It also determines the conditions of climate change which currently have become a real threat to the survival of communities in various parts of the world, including the threat of the sustainability of the crosscreating life-supporting ecosystem.
The study about the efforts to implement the NDCs policy in the Paris Agreement will be conducted by discussing the main defiance and obstacles faced by the parties of the Paris Agreement when implementing their NDCs. Moreover, it will distribute experiences and notion on how to cope with it. Recognizing completion in this way will lead to the expansion of an exhaustive suite of NDCs practice approaches. This approach brings perspectives gleaned from the parties and summarizes groundbreaking ways to improve NDCs practice in various fields. This paper is expected to be able to carry both academic and practical significance. In terms of academic significance, this paper is expected to become a reference for readers to broaden public policy insights regarding efforts to implement NDCs in the Paris Agreement, while on practical significance this paper can be a valuable reference for students in making next paper.

\section{METHODS}

This research uses literature study by collecting data, studies, reports, publications, books and news about obstacles faced by the parties of the Paris Agreement when implementing their NDCs and notion on how to cope with it. According to Creswell [20], the literature study is a written summary of articles from journals, books and other documents that describe theory and information, both past and current, organizing libraries into topics and documents needed for a study. By conducting a literature study, the authors hope to get a collection of perspectives on the implementation efforts of the NDCs under the Paris Agreement.

\section{RESULTS AND DISCUSSION}

NDCs implementation can be categorized into 3 (three) stages [19]. The first stage is the preparation of preconditions which must be completed before 2020. This stage consists of: development of ownership and commitment; capacity building; enabling environment; preparation of communication frameworks and networks; one-data GHG policy; preparation of intervention policies, plans and programs; and preparation of NDCs implementation guidelines, including a review of readiness for the 2020-2030 commitment period. The second phase is the implementation in the first commitment period starting from 2020-2030. The third stage is monitoring and reviewing NDCs during the commitment period, which includes the achievement of targets both in terms of reducing emissions and increasing adaptation capacity as well as increasing resilience including international reporting. This opinion was also supported by Hakim [21] who also explained that NDC, for example, in the country of Indonesia, it is divided into three stages, namely 2015-2019 as preparation, or to support a smooth transition towards readiness for the 20202030 commitment. Second, the range between 2020 and 2030 as the implementation of the first commitment period, and the third phase after 2030 which is a review of the commitment period, including international reporting and target achievements. 
Various countries in the world have made climate policy efforts in their respective regions in order to achieve the NDCs target in the Paris Agreement [15]. A research conducted by Röser et al. [22] pay interest to the way of preparation and implementation stage of NDCs. If the preparation of NDCs is conducted by insufficient or inadequate data and analysis, or with the limitation of support from public and private sectors, then implementation of the NDCs by a country will not be realistic. Therefore, the article written by Röser et al. [22] seeks to explore the conditions of a country to develop NDCs in meeting the objectives of the Paris Agreement. Exploration is focused on three areas that consist from science related to politics and policy. The results of the study indicate that in several countries, especially developing countries, the process of NDCs preparation and implementation had challenges related to supporting in politics, finance, resources, and capacity of stakeholders.

The example of a developing country that facing NDCs preparation and implementation challenges is Indonesia. The NDCs state that emission reduction in Indonesia focuses on five sectors that contribute to efforts to reduce GHG emissions from Business as Usual (BAU) 2030, namely the energy, industry, forestry, agriculture and waste sectors. The Indonesian state delivered a target on NDCs by reducing emissions in 2030 as much as 29 per cent through their own efforts and 41 per cent if there is assistance from international [23].

Research from Sulistiawati [24] tries to describe local regulatory efforts to achieve NDCs targets at the local level of the Indonesian government by examining local government efforts in addressing climate change issues and meeting Indonesia's NDCs targets. Based on this study, Sulistiawati [24] has not found any local regulations that support the national strategy in implementing NDCs. Responding to these problems in Indonesia, Sulistiawati [24] suggested that the Indonesian Ministry of Environment and Forestry needs to reintroduce and socialize Indonesia's NDCs to local levels, encourage ways to reduce GHG, and combat climate change together. Furthermore, to achieve the NDCs, Panggabean [25] states that educational efforts are needed, not only for millennials and communities around forests or peatlands and the private sector but also for children. It is significant to make future generation realizes that protecting the environment is important, especially peatland or forest. Besides, a firmer effort is needed in terms of law enforcement by the Government in dealing with the private sector that is still burning concessions for the benefit of companies.

In the energy sector, national energy policies are contradictory and do not fully support efforts to fulfil the commitments made by the Government of Indonesia in meeting the objectives of the Paris Agreement. The achievement of NDCs in Indonesia can also be hampered by cases of deforestation. In relation to forest and land conversion activities, it is known that the Ministry of Environment and Forestry explained that Indonesia's net deforestation from 2018 to 2019 had a total of 462,400 ha. Muhammad Teguh Surya as
Executive Director of the Madani Sustainable Foundation said that Indonesia still needs more serious efforts to curb the rate of deforestation. This is shown through the comparison of the deforestation area between 2018 and 2019, which is proof that Indonesia can only reduce the deforestation rate of 28,000 hectares (ha). In fact, Indonesia's GHG emission reduction commitment as contained in the NDC, which only tolerates deforestation of 325,000 ha every year starting 2020-2030 or 3.25 million in the next 10 years. This means that in 2020 Indonesia must strive to reduce the area of deforestation to 137,400 ha from 2019. Another challenge in implementing the NDC in 2020 is the realization of the target for peat restoration that is still small, especially in areas with permits or concessions that are only 8 per cent or 143,448 ha of the restoration target in the concession area of a total area of 1.7 million ha [26].

Tacconi et al. [27] stated that even though Indonesia has a commitment to reduce emissions from deforestation and forest degradation, Indonesia is still known as the most significant country in the number of cases of illegal logging and forest clearing. Research conducted by Zuhir et al. [28], mention that data related to the rate and trend of deforestation and forest degradation in Indonesia will still make a large contribution to national GHG emissions. It is because several regulations and policies related to forestry are deemed unable to substantially transform efforts to reduce GHG emissions as expected in NDCs. Constraints on transformation arise due to the ineffectiveness of existing laws and policies, overlapping regulations, law enforcement and sectoral egos so that the synergy in achieving commitment has not been seen.

Cases related to deforestation that have occurred in Indonesia have also occurred in Brazil. However, Brazil has succeeded in overcoming the problem of deforestation due to its very aggressive and strategic forest policies. If Indonesia intends to achieve the fulfillment of NDCs targets in the forestry sector, Indonesia must consider lessons that can be drawn from the efforts that have been applied by Brazil in overcoming cases of emissions resulting from the forestry sector due to a series of illegal logging activities, and so on.

As happened in Indonesia, Vietnam is also an example of a developing country facing challenges related to NDCs implementation. Vietnam has ratified the Paris Agreement in October 2016. Vietnam state delivered a target on NDCs by reducing emissions in 2030 as much as 8 per cent through their own efforts and 25 per cent if there is assistance from international. In a study conducted by Trung et al. [29] can find that Vietnam has a national legal framework that supports the implementation of NDCs. However, despite the favourable conditions noted above, NDCs implementation, particularly in the agricultural sector in Vietnam has many defiance related to how to make people aware and have good capacity, how to create better coordination of institution, how to make a plan and downscale the programs, how to engage stakeholder and solve bad regulation. In Vietnam, awareness of climate change mitigation actions, the Paris Agreement, and NDCs are very limited. Low awareness and knowledge of government 
officials, farmers, agricultural producers and low capacity (technical, infrastructure, human resources) for Measurement, Reporting and Verification (MRV) create significant barriers to implementing NDCs plans.

Another major defiance that could be found is the lack of a strong institutional framework in managing and coordinating the NDCs implementation process. This case can make the distribution of responsibility will be insufficient [30] and act as a serious barrier to achieving the goals of the NDCs. Trung et al. [29] identify that in Vietnam, in the coordination and allocation of resources, there are challenges of insufficient or inadequate institutional arrangements, fund collection and allocation, and cross-sector collaboration in agriculture. Furthermore, there are also shortcomings in terms of instruction and mechanisms to distribute National NDCs plans to the local levels, absence of direction to implement and integrate NDCs in the local areas, unavailability of policies to make private sector participate in supporting the NDCs.

From the obstacles in implementation in Vietnam, Trung et al. [29] provides a summary of recommendations that can address the identified barriers, namely: 1) NDCs activity targets and main streams as an integral part of agricultural sector plans and programs; 2) Mobilizing the media for technology awareness campaigns and practices; 3) Building capacity to the practice of MRV systems; 4) Implementing effectiveness of institutional arrangements for implementation of NDCs; 5) Mobilizing the reinforce from various areas to fund the implementation of agricultural NDCs; 6) Finding additional budgets; 7) Conducting a feasibility study and develop a suitability map for each NDC activity; 8) Providing guidelines for planning NDCs activities at local levels; 9) Improving the cooperative mechanism from the authority to other stakeholders; 10) Developing plan for investments in various areas; 11) Mobilizing the private sector to make integration of NDCs Target across the value chain; 12) Reviewing ongoing adjustment to supply a better framework of regulation and incentive mechanisms for investment.

Apart from being carried out in Indonesia and Vietnam, a study is also conducted in the Belt and Road Initiative (BRI) countries. The countries along the Belt and Road are major suppliers of natural resources and producers of commodities, as well as sources of GHG emissions. Some disputes about potential environmental and climate risks are increasing [31]. Statistics show that in 2015 BRI countries considered for world oil supply (75 per cent), natural gas supply ( 57 per cent), and coal supply (69 per cent). Between 2000 and 2015, $\mathrm{CO}_{2}$ in BRI countries rose by around 85 per cent, that is more than twice the worldwide average. Simultaneously, carbon emissions per unit of GDP in BRI countries are quite strong [31]

Qimin et al. [31] state that the study of NDCs implementation in BRI countries is carried out with scenario analysis to evaluate the implementation status and gaps in the fulfilment of NDCs that have been regulated in the Paris Agreement. Based on this analysis, the researcher finally comes up with policy recommendations on the way of pursuing magnification of ambition to tackle climate change and promoting enriched multilateral cooperation with BRI countries. According to research by Qimin et al. [31] suggest that BRI countries should build up strategic planning to enhance climate action and collaboration under multilateral and bilateral mechanisms to concurrently promote the implementation of an exhaustive, matched, and sovereign Paris Agreement. BRI countries require to encourage agreement, seek equitable and mutually useful solutions to jointly get up climate action, and endure the achievement of the Paris Agreement and its long-term goals.

\section{CONCLUSION}

In conclusion, the implementation efforts to achieve NDCs targets require further identification of problems related to low awareness among policymakers. Another key challenge that needs to be identified relates to the absence of a strong institutional framework to manage and coordinate the NDCs implementation process. Low knowledge capacity and insufficient network of policy implementers can be major barriers to implementing NDCs targets. Besides, a lack of experience in monitoring and evaluation practices can cripple steps towards achieving NDCs targets. As such, there is a need to review current regulations to provide a better regulatory framework and mechanism that can encourage various stakeholders in NDCs implementation.

It is important for countries to implement policy improvements in order to achieve their NDCs targets. Matters related to mitigation and adaptation actions that lead to reducing global emission levels are urgently needed. National and local governments can take further action, and non-state actors can also help to achieve NDCs. The successful implementation of the NDCs should be achieved because it will determine the conditions of climate change which are currently become a real threat to the survival of communities in various parts of the world, including threats to the sustainability of life-supporting ecosystems across generations.

\section{ACKNOWLEDGMENT}

I would like to acknowledge supports from the Indonesian Endowment Fund for Education (LPDP Scholarship) and the University of Indonesia that help me to make this paper is possible to be published.

\section{REFERENCES}

[1] B. Lomborg, "Welfare in the 21st century: Increasing development, reducing inequality, the impact of climate change, and the cost of climate policies," Technological Forecasting \& Social Change, vol. 156, 2020.

[2] P.J. Allen, "Climate Change: It's Our Problem," Pediatric nursing, vol. 41, pp. 42, 2015.

[3] B. Barrett, J.W. Charles, and J.L. Temte, "Climate change, human health, and epidemiological transition," Preventive Medicine, vol. 70, pp. $69-75,2015$ 
[4] E.Y.Y. Chan, J.Y. Ho, H.H.Y. Hung, S. Liu, and H.C.Y. Lam, "Health impact of climate change in cities of middle-income countries: the case of China," British Medical Bulletin, vol. 130, pp. 5-24, 2019.

[5] H. Kan, R. Chen, and S. Tong, "Ambient air pollution, climate change, and population health in China," Environment International, vol. 42, pp. 10-19, 2012.

[6] R. Caruso, I. Petrarca, and R. Ricciuti, "Climate change, rice crops, and violence:Evidence from Indonesia," Journal of Peace Research, vol. 53, pp. 66-83, 2016.

[7] C. Breyer, S. Heinonen, and J. Ruotsalainen, "New consciousness: A societal and energetic vision for rebalancing humankind within the limits of planet Earth,” Technological Forecasting and Social Change, vol. 114 , pp. 7-15, 2017.

[8] M. Yousefi, A. Kafash, N. Valizadegan, S.S. Ilanloo, M. Rajabizadeh, S. Malekoutikhah, \& S. Ashrafi, "Climate Change is a Major Problem for Biodiversity Conservation: A Systematic Review of Recent Studies in Iran,” Contemporary Problems of Ecology, vol. 12, pp. 394-403, 2019.

[9] S. Nunez, E. Arets, R. Alkemade, C. Verwer, and R. Leemans, "Assessing the impacts of climate change on biodiversity: is below $2{ }^{\circ} \mathrm{C}$ enough?" Climatic Change, vol. 154, pp. 351-365, 2019.

[10] N. Nurjoni, Dunia Darurat Iklim Akibat Emisi Karbon. Beritasatu, 2020. [Online] Retrieved from: https://www.beritasatu.com/nasional/594574dunia-darurat-iklim-akibat-emisi-karbon on 31 May 2020

[11] P. Sands, Principles of International Environmental Law, Second Edition. New York: Cambridge University Press, 2003

[12] Directorate General of Climate Change Control, Summary Nationally Determined Contribution (NDC) and Its Progress of Implementation. MENLHK, 2017. [Online] Retrieved from: http://ditjenppi.menlhk.go.id/reddplus/images/adminppi/dokumen/summ ary_NDC_english_opt.pdf on 18 May 2020

[13] Directorate for Development, Economy and Environment, Perubahan Iklim. Kementrian Luar Negeri Republik Indonesia, 2019. [Online] Retrieved https://kemlu.go.id/portal/id/read/96/halaman_list_lainnya/perubahaniklim on 16 May 2020

[14] T. Chevallier, M. Loireau, R. Courault, L. Chapuis-Lardy, T. Desjardins, C. Gomez, \& J. Chotte, "Paris climate agreement: Promoting interdisciplinary science and stakeholders' approaches for multi-scale implementation of continental carbon sequestration," Sustainability (Basel, Switzerland), vol. 12, pp. 6715, 2020.

[15] M. Roelfsema, H.L. van Soest, M. Harmsen, D.P. van Vuuren, C. Bertram, M. den Elzen, and Pacific Northwest National Lab. (PNNL), Richland, WA (United States), "Taking stock of national climate policies to evaluate implementation of the paris agreement," Nature Communications, vol. 11, pp. 2096-12, 2020

[16] V. Tørstad, H. Sælen, and L.S. Bøyum, "The domestic politics of international climate commitments: Which factors explain cross-country variation in NDC ambition?" Environmental Research Letters, vol. 15, pp. 24021, 2020.

[17] K. Levin, D. Rich, Y. Bonduki, M. Comstock, D. Tirpak, H. Mcgray \& D. Waskow, Designing and preparing Intended Nationally Determined Contributions (INDCs). Washington, DC: United Nations Development Program and World Resources Institute, 2015.
[18] W.P. Pauw, P. Castro, J. Pickering, and S. Bhasin, "Conditional nationally determined contributions in the paris agreement: Foothold for equity or achilles heel?" Climate Policy, vol. 20, pp. 468-484, 2020.

[19] N. Masripatin, E. Rachmawaty, Y. Suryanti, H. Setyawan, M. Farid, and N. Iskandar, Strategi Implementasi NDC (Nationally Determined Contribution). Jakarta : Direktorat Jenderal Pengendalian Perubahan Iklim, 2017.

[20] J.W. Creswell, Research Design: Pendekatan Kualitatif, Kuantitatif, dan Mixed. Yogyakarta: Pustaka Pelajar, 2009.

[21] A.Y. Hakim, NDC Indonesia sebagai Komitmen Turunkan Karbon. Ecolify, 2020. [Online] Retrieved from https://ecolify.org/blog/ndcindonesia-sebagai-komitmen-turunkan-emisi-karbon on 27 August 2020

[22] F. Röser, O. Widerberg, N. Höhne, and T. Day, "Ambition in the making: Analysing the preparation and implementation process of the nationally determined contributions under the paris agreement," Climate Policy: Special Issue: Making Climate Action More Effective: Lessons Learned from the First Nationally Determined Contributions (NDCs), vol. 20, pp. 415-429, 2020.

[23] D.E. Hindarto, A. Samyanugraha, and D. Nathalia, Pengantar Pasar Karbon untuk Pengendalian Perubahan Iklim. Jakarta Pusat: PMR Indonesia, 2018

[24] L.Y. Sulistiawati, "Indonesia's climate change national determined contributions, a farfetch dream or possible reality?" IOP Conference Series: Earth and Environmental Science, vol. 423, pp. 12022, 2020.

[25] B.T.G.B. Panggabean, Kesiapan Indonesia dalam Memenuhi Nationally Determined Contribution (NDC) sebagai Implementasi Paris Agreement Terkait Restorasi Lahan Gambut. Jakarta: Fakultas Ilmu Hukum, Universitas Indonesia, 2020.

[26] I. Susanto, Deforestasi Mencapau 462.400 Hektar. Kompas, 2020 [Online] Retrieved from: https://bebas.kompas.id/baca/bebasakses/2020/04/24/deforestasi-mencapai-462-400-hektar/ on 18 May 2020.

[27] L. Tacconi, R.J. Rodrigues, and A. Maryudi, "Law enforcement and deforestation: Lessons for Indonesia from Brazil," Forest Policy and Economics, vol. 108, pp. 101943, 2019.

[28] M.A. Zuhir, I. Nurlinda, A.A. Imami, and I. Dajaan, "Indonesia Pasca Ratifikasi Perjanjian Paris 2015; Antara Komitmen dan Realitas," Bina Hukum Lingkungan, vol. 1, pp. 231-248, 2017

[29] N.D. Trung, N.T. Thang, L.H. Anh, T.S.A. Babu, and L. Sebastian, "Analysing the challenges in implementing vietnam's nationallydetermined contribution (NDC) in the agriculture sector under the current legal, regulatory and policy environment," Cogent Environmental Science, vol. 6, 2020

[30] C. Clar, A. Prutsch, and R. Steurer, "Barriers and guidelines for public policies on climate change adaptation: A missed opportunity of scientific knowledge-brokerage," Natural Resources Forum, vol. 37, pp. 1-18, 2013.

[31] C. Qimin, F. Sha, and W. Xinyuan, "Modeling the implementation of NDCs and the scenarios below $2{ }^{\circ} \mathrm{C}$ for the belt and road countries," Ecosystem Health and Sustainability, ahead-of-print(ahead-of-print), $1766998,2020$. 